\title{
Correlated evolution between herbivory and gastrointestinal tract in a prolific lizard adaptive radiation
}

\author{
Daniel Pincheira-Donoso* \\ MacroBiodiversity Lab, School of Biological Sciences, Queen's University Belfast, 19 Chlorine \\ Gardens, Belfast, BT9 5DL, UK
}

Submitted: May 25, 2020. Final revision received: November 4, 2020. Accepted: February 3, 2021

\begin{abstract}
Radiations of ectothermic vertebrates across cold climates depend on the coordinated evolution of multiple traits that compensate for the constraints imposed by limited and fluctuating resources, such as temperature, food and oxygen. One of nature's most prolific such radiations, Liolaemus lizards, has diversified across the extreme cold climates of the Andes and Patagonia. Remarkably, the prevailing patterns of reptile herbivory are opposed by Liolaemus which, in contrast with lizards generally, have repeatedly evolved plant consumption across small-bodied species from cold climates. Herbivory is hypothesized to depend on the evolution of multiple traits that maximize absorption of nutrients from an intrinsically poor-quality diet, such as increases in gastrointestinal tract size and increases in the density of nematodes in the intestine that may assist with plant digestion. Here, a comparative phylogenetic approach across Liolaemus species is implemented to test these hypotheses, which have only been investigated nonphylogenetically. Results reveal that intestine length increases consistently with increasing herbivory, whereas stomach size or nematode load are not associated with plant consumption. Body size plays no role in herbivory either. Consequently, this evidence places emphasis on the enlargement of the intestine to facilitate the evolution of herbivory in cold climates.
\end{abstract}

\section{Keywords}

Body size; cold climates; diet; gut size; Liolaemus; nematodes

\section{Introduction}

Lizards have radiated across most regions on Earth, including extreme cold climates at high latitudes and elevations (Pianka \& Vitt, 2003; Pough et al., 2015; Roll et al., 2017; Vidan et al., 2019). Evidence suggests that the saturation of novel ecological opportunities encountered by ancestral lineages in such environments was

*) E-mail: D.Pincheira-Donoso@qub.ac.uk 
facilitated by innovative adaptations in life history (Shine, 2005; Pincheira-Donoso et al., 2013; Ma et al., 2018), ecophysiological (Meiri et al., 2013; Pough et al., 2015) and ecological traits (Pough, 1973; Espinoza et al., 2004; Sites et al., 2011), whereas the role of body size remains contested (Slavenko et al., 2019).

The evolution of herbivory has been implicated with the prolific radiation of Liolaemus lizards across the Andes and Patagonia in South America (Espinoza et al., 2004; Reaney et al., 2018). In fact, while herbivory has predominantly evolved among large-sized, warm-climate lizards that maintain high body temperatures (Pough, 1973; Iverson, 1982; King, 1996; Vitt, 2004), plant consumption has evolved in multiple independent episodes across small-sized Liolaemus species from cold climates that maintain low body temperatures (Espinoza et al., 2004; O'Grady et al., 2005). A potential explanation for these unusual correlated adaptations with herbivory is that low climatic temperatures are counterbalanced by increasing rates of body heating in species with smaller body sizes, thus facilitating digestion of plant matter (Espinoza et al., 2004; Pincheira-Donoso et al., 2008). However, given the poorly nutritious, fibrous nature of plants (Karasov \& Martinez del Rio, 2007), and the lack of enzymes for their digestion in vertebrates (Stevens \& Hume, 1995), it has been hypothesized that enlargements of the gastrointestinal tract (Chivers \& Hladik, 1980; Schieck \& Millar, 1985; O'Grady et al., 2005; German et al., 2010), and increases in the nematode and microbe colonies in the gut (Sokol, 1967; Nagy, 1977; Iverson, 1982; Dearing, 1993; O'Grady et al., 2005) would critically contribute to maximize rates of nutrient absorption. Although these hypotheses can have key implications for our understanding of the changes undergone by ectotherms during invasions of cold climates, only one comparative, but nonphylogenetic study has addressed them in Liolaemus (O'Grady et al., 2005).

Here, I implement a comparative phylogenetic study to investigate the hypotheses that herbivory is associated with enlargement of the gastrointestinal tract and with larger body size, and that plant consumption correlates positively with the density of nematode gut colonies across Liolaemus species varying extensively in their geographic locations, body sizes and levels of herbivory.

\section{Materials and methods}

To investigate the above hypotheses about correlated evolution with transitions to herbivory, I compiled a comparative dataset spanning body size, gastrointestinal tract, population density of gut nematode colonies, and dietary data from 19 species of the Liolaemus genus distributed across a wide range of climatic and geographic regions (Supplementary table S1). First, I obtained fine-scale dietary data by direct surgical inspection of the gut contents of 422 preserved specimens, given the advantages of this method for accurate estimation of diet relative to other widely used methods, such as fecal analyses (Pincheira-Donoso, 2008). The gut contents of each individual specimen were spread in water in a Petri dish to count the numerical frequency of each dietary item, and to estimate their volume calculated from measures 
of length and width. To estimate relative volumes of plant versus animal matter, the Petri dish was placed on a graph paper sheet with identical quadrats - the number of quadrats covered with each of these items was then scaled to $100 \%$ to work out the relative contribution of each to the total gut content volume. Second, I used snout-vent length (SVL) as a proxy for body size, given its predominant use in studies of lizards (Meiri, 2008), and given its widespread correlation with life history, ecological and morphological traits (Peters, 1983; Shine, 2005; Pincheira-Donoso \& Hunt, 2017; Stark et al., 2020), including in Liolaemus (Espinoza et al., 2004; Pincheira-Donoso \& Tregenza, 2011; Pincheira-Donoso et al., 2018). Third, measures of gastrointestinal tract length were taken separately for stomach and intestine given that fermentation and absorption of nutrients is known to predominantly take place in the intestine (Stevens \& Hume, 1995; O'Grady et al., 2005). Therefore, the effects of selection on gut length are expected to differ between these two regions of the tract, even if the lengths of both structures scale allometrically to some extent. Finally, nematode colonies were measured by counting the total number of individual nematodes found along the intestine.

All analyses were performed using a Liolaemus molecular phylogenetic tree (Pincheira-Donoso et al., 2017) containing 15 out of the 19 species in our dataset. Prior to analyses, all variables were transformed to natural logarithms to meet assumptions of parametric analyses (Zar, 2009). To perform tests of the hypotheses, we implemented a series of phylogenetic linear models in the R package nlme (Pinheiro et al., 2018). Given the strong allometric association of the components of the gastrointestinal tract (stomach and intestine) with body size (see Results and discussion, below), for the tests of the core hypotheses that the lengths of these anatomical structures are a function of variation in the degree of herbivory, we performed phylogenetic analyses of covariance with SVL as covariate to control for the effects of body size. These analyses were performed using the same package nlme. All analyses were conducted in the software R (R Development Core Team, 2017).

\section{Results and discussion}

Levels of herbivory vary extensively across Liolaemus species, ranging from $2.81 \pm$ $7.69 \%$ of the entire volume of dietary contents in L. monticola (range: $0-30 \%$, median: $0 \%$ ) to $81 \pm 25.69 \%$ in L. jamesi (range: $7.5-100 \%$, median: $90 \%$ ). Contrary to predictions, regression analyses failed to identify an effect of body size on the proportion of plant matter across the diets of species when performing phylogenetic (estimate $=-0.88, t=-0.7, \mathrm{df}=13, P=0.49, n=15$ ) and conventional analyses $\left(R^{2}=0.06, F_{1,17}=1.08, t=1.04, P=0.31, n=19\right.$ species; fig. 1a). Increases in body size, however, strongly predicted increases in both stomach $\left(R^{2}=0.68, F_{1,17}=35.31, t=5.94, P<0.00001, n=19\right)$ and intestine length $\left(R^{2}=0.54, F_{1,17}=19.84, t=4.45, P<0.001, n=19\right)$, whereas stomach and intestine lengths correlated positively $(r=0.77, P<0.05)$. Although reptile 
herbivory has predominantly been associated with larger body size (Pough, 1973; Cooper \& Vitt, 2002), and this prediction was previously supported by nonphylogenetic evidence in a set of Liolaemidae species (O'Grady et al., 2005), it is not surprising to find the opposite relationship. In a comparative study, Espinoza et al. (2004) showed that herbivory in Liolaemidae deviates from the well-established "rules of reptilian herbivory"(Vitt, 2004), as these lizards have high levels of plant consumption in cold environments and small body sizes. The diversification of Liolaemidae lizards was accelerated by their occupation of the vast ecological opportunity that emerged with the uplift of the Andes (Pincheira-Donoso et al., 2015; Reaney et al., 2018; Esquerré et al., 2019), creating hotspots of species richness toward high, cold-climate elevations (Schulte et al., 2000; Pincheira-Donoso et al., 2018; Jara et al., 2019). Given the strong ecophysiological constraints imposed by low temperatures, the successful radiation of Liolaemidae across the extreme Andean and Patagonian climates has been associated with their reductions in body size, which would facilitate more effective thermoregulation for metabolic processes, including digestion of increased proportions of plant matter in their diets (Espinoza et al., 2004; Pincheira-Donoso et al., 2008). Why are herbivorous Liolaemus not consistently smaller in body size then? Very likely because herbivory is also common among Liolaemus species from low-elevation deserts (DonosoBarros, 1966; Cei, 1993; Pincheira-Donoso \& Núñez, 2005), which would therefore erode an ecogeographical signal.

Tests of the second hypothesis that increased levels of herbivory are associated with an enlargement of the gastrointestinal tract confirmed a significant increase in intestine length as the proportion of plant matter increases when performing both conventional $\left(F_{2,16}=9.89\right.$, estimate $=0.11, P<0.01, n=19$ species; fig. $\left.1 \mathrm{~b}\right)$ and phylogenetic analyses of covariance with SVL as covariate $\left(F_{2,12}=9.01\right.$, estimate $=0.11, P=0.01, n=15$ species). Therefore, these findings are consistent with the expectation that transitions toward herbivory correlate with increased intestine surface to maximize the absorption of nutrients. However, whereas the length of the stomach shows a slight tendency to elongate with increasing herbivory across species, this association remained nonsignificant with both conventional $\left(F_{2,16}=3.73\right.$, estimate $=0.05, P=0.07, n=19$ species; fig. $\left.1 \mathrm{c}\right)$ and phylogenetic analyses of covariance with SVL as covariate $\left(F_{2,12}=3.57\right.$, estimate $=0.05$, $P=0.08, n=15)$. Such discrepancy between the enlargement of the intestine and stomach can be interpreted as further support for the hypothesis that increasing herbivory relies on anatomical adjustments that maximize the absorption of nutrients from an intrinsically low-energy diet (Karasov \& Martinez del Rio, 2007; Smil, 2013; Scharf et al., 2015), which takes place mostly in the intestine. It remains possible that variation in the length of gut structures is not exclusively adaptive, but also influenced by phenotypic plasticity (Naya et al., 2007; Zandonà et al., 2015; Kohl et al., 2016). This hypothesis is an interesting prospect for further comparative studies. 

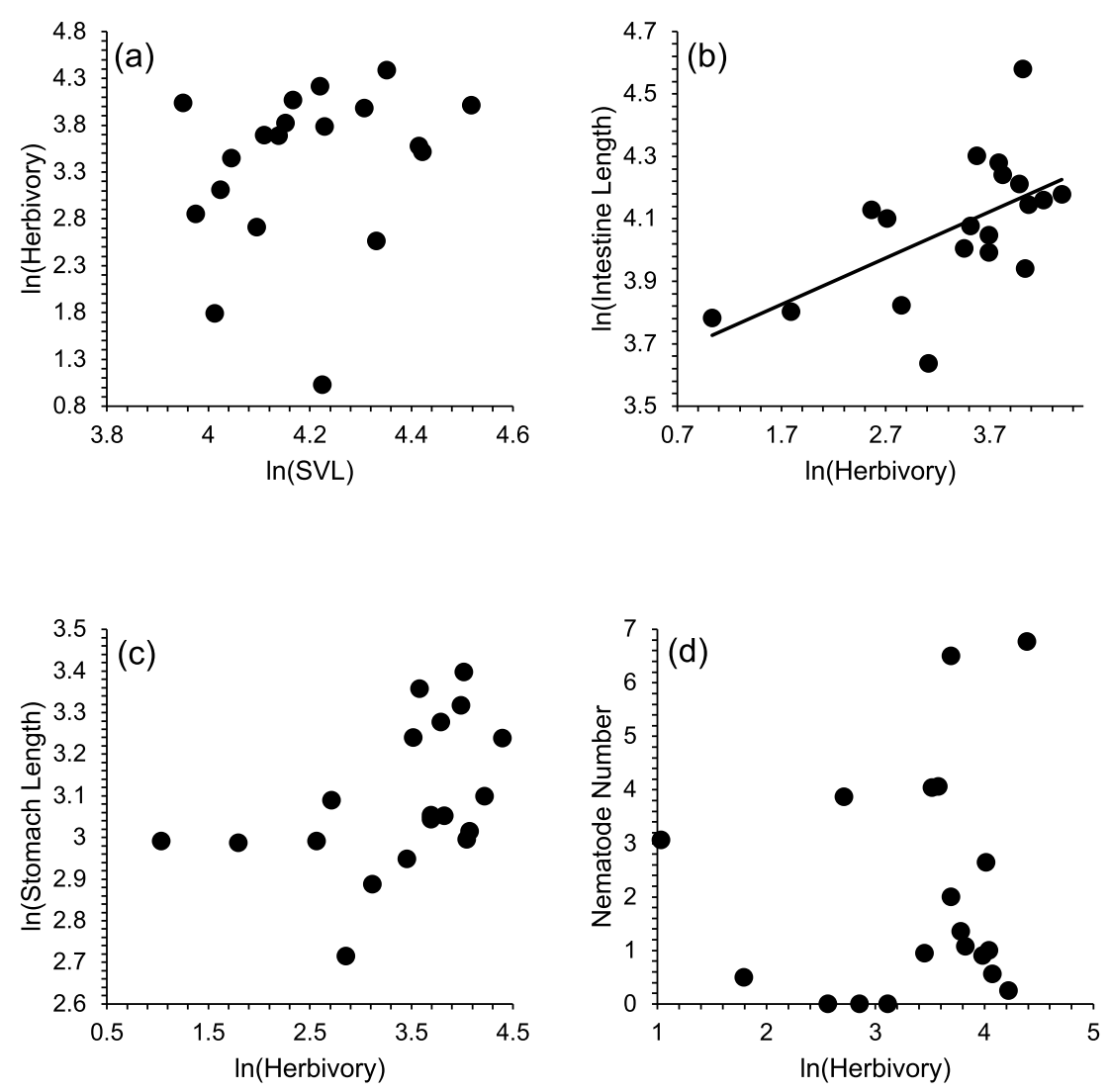

Figure 1. Associations between herbivory and multiple traits across Liolaemus species. Increases in body size do not predict increasing herbivory (a). In contrast, components of the gastrointestinal tract length increase with increasing proportions of plant consumption, although this relationship is only significant for intestine length (b) but not for stomach length (c). No evidence for an association between herbivory and the density of nematode colonies in the gut was observed (d).

Finally, the third hypothesis that increased levels of herbivory are associated with higher nematode load was rejected by both conventional $\left(R^{2}=0.02, F_{1,17}=0.34\right.$, $t=0.59, P=0.57, n=19$; fig. 1d) and phylogenetic analyses (estimate $=0.27$, $t=0.52, \mathrm{df}=13, P=0.62$ ). Parasite number is not influenced by body size either (estimate $=1.9, t=0.88, \mathrm{df}=13, P=0.39, n=15$ ). Therefore, in contrast with previous nonphylogenetic evidence (O'Grady et al., 2005), these results fail to attribute to nematode colonies a role in the digestion of plant matter in Liolaemus. In contrast, this role may in fact be played by microbial colonies, which have been found to be linked with plant consumption in these lizards (Kohl et al., 2016, 2017).

Collectively, these findings identify a primary role for intestine evolution in the transitions toward herbivory in Liolaemus lizards, challenging the previously suggested roles for body size and nematode load (O'Grady et al., 2005). More widely, 
these findings suggest interesting opportunities to address the impact that the significant enlargement of a highly energetically costly trait (i.e., the gastrointestinal tract) can have on the expression of trade-offs with other energetically costly traits during evolutionary radiation across extreme climates. Key biological processes such as brain development (Aiello \& Wheeler, 1995; Striedter, 2005; Smil, 2013) and reproduction (Roff, 2002; Scharf et al., 2015) are energy-demanding and could therefore be prime candidate traits to be affected by trade-offs resulting from the allocation of energy into gastrointestinal enlargement during herbivory evolution (Aiello \& Wheeler, 1995; Kaufman et al., 2003).

\section{Acknowledgements}

The author is grateful to Herman Núñez and Jhoann Canto from the National Museum of Natural History of Santiago, Chile, for providing access to the Liolaemus collection. The author also acknowledges the financial support provided by the Leverhulme Trust and by Queen's University Belfast School of Biological Sciences. Two anonymous referees and the editor made insightful recommendations that improved the manuscript considerably.

\section{Supplementary material}

Supplementary material is available online at: https://doi.org/10.6084/m9.figshare.14035004

\section{References}

Aiello, L.C. \& Wheeler, P. (1995) The expensive-tissue hypothesis: the brain and the digestive system in human and primate evolution. Curr. Anthropol., 36, 199-221. DOI:10.1086/204350.

Cei, J.M. (1993) Reptiles del Noroeste, Nordeste y Este de la Argentina. Herpetofauna de las Selvas Subtropicales, Puna y Pampas. Museo Regionale di Scienze Naturali, Turin, Italy.

Chivers, D.J. \& Hladik, C.M. (1980) Morphology of the gastrointestinal tract in primates: comparisons with other mammals in relation to diet. J. Morphol., 166, 337-386. DOI:10.1002/jmor.1051660306.

Cooper, W.E. \& Vitt, L.J. (2002) Distribution, extent, and evolution of plant consumption by lizards. J. Zool., 257, 487-517. DOI:10.1017/S0952836902001085.

Dearing, M.D. (1993) An alimentary specialization for herbivory in the tropical whiptail lizard Cnemidophorus murinus. J .Herpetol., 27, 111-114. DOI:10.2307/1564920.

Donoso-Barros, R. (1966) Reptiles de Chile. Ediciones Universidad de Chile, Santiago, Chili.

Espinoza, R.E., Wiens, J.J. \& Tracy, C.R. (2004) Recurrent evolution of herbivory in small, coldclimate lizards: breaking the ecophysiological rules of reptilian herbivory. Proc. Natl Acad. Sci. USA, 101, 16819-16824. DOI:10.1073/pnas.0401226101.

Esquerré, D., Brennan, I.G., Catullo, R.A., Torres-Pérez, F. \& Keogh, J.S. (2019) How mountains shape biodiversity: the role of the Andes in biogeography, diversification, and reproductive biology in South America's most species-rich lizard radiation (Squamata: Liolaemidae). Evolution, 73, 214-230. DOI:10.1111/evo.13657. 
German, D.P., Nagle, B.C., Villeda, J.M., Ruiz, A.M., Thomson, A.W., Contreras Balderas, S. \& Evans, D.H. (2010) Evolution of herbivory in a carnivorous clade of minnows (Teleostei: Cyprinidae): effects on gut size and digestive physiology. Physiol. Biochem. Zool., 83, 1-18. DOI: $10.1086 / 648510$.

Iverson, J.B. (1982) Adaptations to Herbivory in iguanine lizards. In: G.M. Burghardt \& A.S. Rand (Eds) Iguanas of the World. Their Behaviour,Ecology and Conservation, pp. 60-76. Noyes Publications, Park Ridge, NJ, USA.

Jara, M., García-Roa, R., Escobar, L.E., Torres-Carvajal, O. \& Pincheira-Donoso, D. (2019) Alternative reproductive adaptations predict asymmetric responses to climate change in lizards. Sci. Rep., 9, 5093. DOI:10.1038/s41598-019-41670-8.

Karasov, W.H. \& Martinez del Rio, C. (2007) Physiological Ecology. How Animals Process Energy, Nutrients, and Toxins. Princeton University Press, Princeton, NJ, USA.

Kaufman, J.A., Hladik, C.M. \& Pasquet, P. (2003) On the expensive-tissue hypothesis: independent support from highly encephalized fish. Curr. Anthropol., 44, 705-707. DOI:10.1086/379258.

King, G. (1996) Reptiles and Herbivory. Chapman \& Hall, London, UK.

Kohl, K.D., Brun, A., Magallanes, M., Brinkerhoff, J., Laspiur, A., Acosta, J.C., Bordenstein, S.R. \& Caviedes-Vidal, E. (2016) Physiological and microbial adjustments to diet quality permit facultative herbivory in an omnivorous lizard. J. Exp. Biol., 219, 1903-1912. DOI:10.1242/jeb.138370.

Kohl, K.D., Brun, A., Magallanes, M., Brinkerhoff, J., Laspiur, A., Acosta, J.C., Caviedes-Vidal, E. \& Bordenstein, S.R. (2017) Gut microbial ecology of lizards: insights into diversity in the wild, effects of captivity, variation across gut regions and transmission. Mol. Ecol., 26, 1175-1189. DOI:10.1111/mec.13921.

Ma, L., Buckley, L.B., Huey, R.B. \& Du, W.-G. (2018) A global test of the cold-climate hypothesis for the evolution of viviparity of squamate reptiles. Glob. Ecol. Biogeogr., 27, 679-689. DOI:10. 1111/geb.12730.

Meiri, S. (2008) Evolution and ecology of lizard body sizes. Glob. Ecol. Biogeogr., 17, 724-734. DOI:10.1111/j.1466-8238.2008.00414.x.

Meiri, S., Bauer, A.M., Chirio, L., Colli, G.R., Das, I., Doan, T.M., Feldman, A., Castro-Herrera, F., Novosolov, M., Pafilis, P., Pincheira-Donoso, D., Powney, G., Torres-Carvajal, O., Uetz, P. \& Van Damme, R. (2013) Are lizards feeling the heat? A tale of ecology and evolution under two temperatures. Glob. Ecol. Biogeogr., 22, 834-845. DOI:10.1111/geb.12053.

Nagy, K.A. (1977) Cellulose digestion and nutrient assimilation in Sauromalus obesus, a plant eating lizard. Copeia, 1977, 355-362. DOI:10.2307/1443915.

Naya, D.E., Karasov, W.H. \& Bozinovic, F. (2007) Phenotypic plasticity in laboratory mice and rats: a meta-analysis of current ideas on gut size flexibility. Evol. Ecol. Res., 9, 1363-1374.

O'Grady, S.P., Morando, M., Avila, L. \& Dearing, M.D. (2005) Correlating diet and digestive tract specialization: examples from the lizard family Liolaemidae. Zoology, 108, 201-210. DOI:10.1016/j. zool.2005.06.002.

Peters, R.H. (1983) The Ecological Implications of Body Size. Cambridge University Press, Cambridge, UK.

Pianka, E.R. \& Vitt, L.J. (2003) Lizards. Windows to the Evolution of Diversity. University of California Press, Berkeley, CA, USA.

Pincheira-Donoso, D. (2008) Testing the accuracy of fecal-based analyses in studies of trophic ecology in lizards. Copeia, 2008, 322-325. DOI:10.1643/CE-06-214.

Pincheira-Donoso, D. \& Hunt, J. (2017) Fecundity selection theory: concepts and evidence. Biol. Rev., 92, 341-356. DOI:10.1111/brv.12232. 
Pincheira-Donoso, D. \& Núñez, H. (2005) Las especies chilenas del género Liolaemus. Taxonomía, sistemática y evolución. Publ. Oc. Mus. Nac. Hist Nat. Chile, 59, 1-487.

Pincheira-Donoso, D. \& Tregenza, T. (2011) Fecundity selection and the evolution of reproductive output and sex-specific body size in the Liolaemus lizard adaptive radiation. Evol. Biol., 38, 197207. DOI:10.1007/s11692-011-9118-7.

Pincheira-Donoso, D., Hodgson, D.J. \& Tregenza, T. (2008) The evolution of body size under environmental gradients in ectotherms: why should Bergmann's rule apply to lizards? BMC Evol. Biol., 8, 68. DOI:10.1186/1471-2148-8-68.

Pincheira-Donoso, D., Tregenza, T., Witt, M.J. \& Hodgson, D.J. (2013) The evolution of viviparity opens opportunities for lizard radiation but drives it into a climatic cul-de-sac. Glob. Ecol. Biogeogr., 22, 857-867. DOI:10.1111/geb.12052.

Pincheira-Donoso, D., Harvey, L.P. \& Ruta, M. (2015) What defines an adaptive radiation? Macroevolutionary diversification dynamics of an exceptionally species-rich continental lizard radiation. BMC Evol. Biol., 15, 153. DOI:10.1186/s12862-015-0435-9.

Pincheira-Donoso, D., Jara, M., Reaney, A., García-Roa, R., Saldarriaga-Córdoba, M. \& Hodgson, D.J. (2017) Hypoxia and hypothermia as rival agents of selection driving the evolution of viviparity in lizards. Glob. Ecol. Biogeogr., 26, 1238-1246. DOI:10.1111/geb.12626.

Pincheira-Donoso, D., Tregenza, T., Butlin, R.K. \& Hodgson, D.J. (2018) Sexes and species as rival units of niche saturation during community assembly. Glob. Ecol. Biogeogr., 27, 593-603. DOI:10. 1111/geb.12722.

Pinheiro, J., Bates, D., DebRoy, S. \& Sarkar, D. (2018) nlme: Linear and Nonlinear Mixed Effects Models. R package version 3, 1-137. https://CRAN.R-project.org/package=nlme.

Pough, F.H. (1973) Lizard energetics and diet. Ecology, 54, 837-844. DOI:10.2307/1935678.

Pough, F.H., Andrews, R.M., Crump, M.L., Savitzky, A.H., Wells, K.D. \& Brandley, M.C. (2015) Herpetology. 4th Edition. Oxford University Press, Oxford, UK.

R Development Core Team (2017) R: A Language and Environment for Statistical Computing. R Foundation for Statistical Computing, Vienna, Austria. https://cran.r-project.org.

Reaney, A.M., Saldarriaga-Córdoba, M. \& Pincheira-Donoso, D. (2018) Macroevolutionary diversification with limited niche disparity in a species-rich lineage of cold-climate lizards. BMC Evol. Biol., 18, 16. DOI:10.1186/s12862-018-1133-1.

Roff, D.A. (2002) Life History Evolution. Sinauer Associates, Sunderland, MA, USA.

Roll, U., Feldman, A., Novosolov, M., Allison, A., Bauer, A.M., Bernard, R., Böhm, M., CastroHerrera, F., Chirio, L., Collen, B., Colli, G.R., Dabool, L., Das, I., Doan, T.M., Grismer, L.L., Hoogmoed, M., Itescu, Y., Kraus, F., LeBreton, M., Lewin, A., Martins, M., Maza, E., Meirte, D., Nagy, Z.T., Nogueira, C. de C., Pauwels, O.S.G., Pincheira-Donoso, D., Powney, G.D., Sindaco, R., Tallowin, O.J.S., Torres-Carvajal, O., Trape, J.-F., Vidan, E., Uetz, P., Wagner, P., Wang, Y., Orme, C.D.L., Grenyer, R. \& Meiri, S. (2017) The global distribution of tetrapods reveals a need for targeted reptile conservation. Nat. Ecol. Evol., 1, 1677-1682. DOI:10.1038/s41559-017-0332-2.

Scharf, I., Feldman, A., Novosolov, M., Pincheira-Donoso, D., Das, I., Böhm, M., Uetz, P., TorresCarvajal, O., Bauer, A., Roll, U. \& Meiri, S. (2015) Late bloomers and baby boomers: ecological drivers of longevity in squamates and the tuatara. Glob. Ecol. Biogeogr., 24, 396-405. DOI:10. 1111 /geb.12244.

Schieck, J.O. \& Millar, J.S. (1985) Alimentary tract measurements as indicators of diets of small mammals. Mammalia, 49, 93-104. DOI:10.1515/mamm.1985.49.1.93. 
Schulte, J.A., Macey, J.R., Espinoza, R.E. \& Larson, A. (2000) Phylogenetic relationships in the iguanid lizard genus Liolaemus: multiple origins of viviparous reproduction and evidence for recurring Andean vicariance and dispersal. Biol. J. Linn. Soc., 69, 75-102. DOI:10.1111/j.1095-8312. 2000.tb01670.x.

Shine, R. (2005) Life-history evolution in reptiles. Annu. Rev. Ecol. Evol. Syst., 36, 23-46. DOI:10. 1146/annurev.ecolsys.36.102003.152631.

Sites, J.W., Reeder, T.W. \& Wiens, J.J. (2011) Phylogenetic insights on evolutionary novelties in lizards and snakes: sex, birth, bodies, niches, and venom. Annu. Rev. Ecol. Evol. Syst., 42, 227244. DOI:10.1146/annurev-ecolsys-102710-145051.

Slavenko, A., Feldman, A., Allison, A., Bauer, A.M., Böhm, M., Chirio, L., Colli, G.R., Das, I., Doan, T.M., LeBreton, M., Martins, M., Meirte, D., Nagy, Z.T., Nogueira, C. de C., Pauwels, O.S.G., Pincheira-Donoso, D., Roll, U., Wagner, P., Wang, Y. \& Meiri, S. (2019) Global patterns of body size evolution in squamate reptiles are not driven by climate. Glob. Ecol. Biogeogr., 28, 471-483. DOI:10.1111/geb.12868.

Smil, V. (2013) Should We Eat Meat? Evolution and Consequences of Modern Carnivory. WileyBlackwell, Oxford, UK. DOI:10.1002/9781118278710.

Sokol, O.M. (1967) Herbivory in lizards. Evolution, 21, 192-194. DOI:10.2307/2406753.

Stark, G., Pincheira-Donoso, D. \& Meiri, S. (2020) No evidence for the 'rate-of-living' theory across the tetrapod tree of life. Glob. Ecol. Biogeogr., 29, 857-884. DOI:10.1111/geb.13069.

Stevens, C.E. \& Hume, I.D. (1995) Comparative Physiology of the Vertebrate Digestive System. Cambridge University Press, Cambridge, UK.

Striedter, G.F. (2005) Principles of Brain Evolution. Sinauer, Sunderland, MA, USA.

Vidan, E., Novosolov, M., Bauer, A., Castro Herrera, F., Chirio, L., Nogueira, C. de C., Doan, T.M., Lewin, A., Meirte, D., Nagy, Z.T., Pincheira-Donoso, D., Tallowin, O.J.S., Torres Carvajal, O., Uetz, P., Wagner, P., Wang, Y., Belmaker, J. \& Meiri, S. (2019) The global biogeography of lizard functional groups. J. Biogeogr., 46, 2147-2158. DOI:10.1111/jbi.13667.

Vitt, L.J. (2004) Shifting paradigms: herbivory and body size in lizards. Proc. Natl Acad. Sci. USA, 101, 16713-16714. DOI:10.1073/pnas.0407439101.

Zandonà, E., Auer, S.K., Kilham, S.S. \& Reznick, D.N. (2015) Contrasting population and diet influences on gut length of an omnivorous tropical fish, the Trinidadian guppy (Poecilia reticulata). PLoS ONE, 10, e0136079. DOI:10.1371/journal.pone.0136079.

Zar, J.H. (2009) Biostatistical Analysis. Prentice-Hall, Upper Saddle River, NJ, USA. 